\title{
トラス構造の製作形状および施工経路最適化解析 OPTIMIZATION ANALYSIS FOR INITIAL SHAPE AND CONSTRUCTION PROCESS OF TRUSS STRUCTURES
}

\author{
兼光知 巳*, 半谷裕. 彦** \\ Tomomi KANEMITSU and Yasuhiko HANGAI
}

The following two analytical problems for supporting the construction planning of structures by using computers are studied: (1) Analysis of initial shape before construction

An analysis of initial shape before construction with estimating construction process is proposed in this paper. An example of truss structures is analyzed.

(2) Inverse analysis for construction process by removing members

An inverse analysis for construction process by removing members is proposed in order to find an optimum solution of the construction process satisfying given criteria. The analysis searches for a construction process satisfying given criteria by removing members in order from a finished structure. Examples of truss structures are analyzed.

Keywords: Construction planning, Initial shape before construction, Construction process, Optimization, Inverse analysis 施工計画, 製作形状, 施工経路, 最適化, 逆解析

1. はじめに

建築構造物の施工は, 完成構造物を建設機械等が取り扱える規模 のブロックに分割し，それらのブロックを組み立てることによって 行われる。そのため, 建築構造物の構造特性は施工時と完成時とで は異なる。従って, 建築構造物の生産計画 (設計および施工計画)で は, 完成時の構造特性のみならず, 施工時の構造特性にも十分注意 を払う必要がある。一般的に, 施工計画は過去の実績あるいは経験 に基づいて行われ，そのため, 施工計画は試行錯誤的作業が多く，作 業量も多くなる傾向にある1)。施工計画作業の効率化を図る手段とし

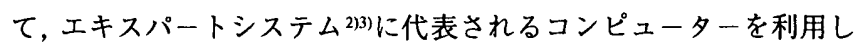
た施工計画支援が考えられるり。

本論文では、コンピューターを利用した施工計画支援という観点 から, 施工計画の中で以下に示す(1)(2)の2つの問題について解析的 検討を行う。

\section{(1)製作形状決定問題}

施工後の完成形状と設計で目標とする形状とが異なり，設計上問 題となる場合, ブロックを組み立てる前に製作キャンバー（設計荷 重によるたわみを調整するために設けるむくり）を設ける，あるい はブロックの架設位置を変化させるなどして製作形状の調整を行う。 そのため, 製作形状は施工経路および施工時の変形性状を考慮して
決定する必要がある。しかし，従来の製作形状の決定は，完成構造 物の長期設計荷重時における変形分をむくりとして与えるなど, 完 成時の構造物における変形性状のみを評価することによって行われ， 施工時の変形性状は考慮されないことが多い4)。本論文では, 施工経 路を考慮して, 完成時の目標形状を渵足させるように，施工前の構 造部材の製作形状を求める解析方法について検討する

\section{(2)施工経路最適化問題}

通常，架設手順の計画は，数種類の架設計画案を作成し，各案を 品質・コスト・工期・安全性などの観点から検討・評価し, 最も評 価が高い計画案を実施計画案とするという手順で行われる6。架設計 画案の作成は実績と経験によるところが多く，検討・評価は試行錯 誤的作業によって行われる場合が多い。そのため,作業量は多く，ま た, 最終的に決定された実施計画案が目標を満足する最適解か否か の判断は困難である。本論文では, 構造的目標を満足するように, 構 造部材の架設手順を求める解析方法を検討する。

\section{2. 製作形状決定問題の解析 \\ 2.1 構造物の施工時の变形性状}

本節では簡単な例として, 図 1 に示すトラス構造物の施工時の変 形性状を調べる。施工手順を図 2 に示す。施工時の荷重は自重（等

\footnotetext{
* 清水建設(枆技術研究所 研究買

** 東京大学生産技術研究所 教授・工博
} 
分布荷重)のみとし, 全荷重がプロセス-1で裁荷されるものとする。 荷重が载荷される前のプロセス -1 における初期形状は図 1 に示すよ うなフラットとする。本構造物の荷重と変位の関係は, 各施工プロ セスにおいて線形とし, 各プロセスの変形解析は微小変形理論に基

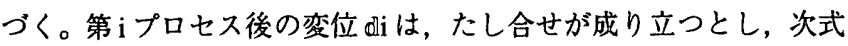
によって計算する。

$$
d \mathrm{j}=\sum_{\mathrm{k}=1}^{\mathrm{i}} \mathbb{d}_{\mathrm{k}}
$$

ここに，訨は第 $\mathrm{k}$ プロセスの変位である。

図 3 の実線は，施工時における荷重係数とA 点（図 1 参照）の鉛 直変位の関係を示したものである。ここに，荷重係数は荷重／全荷 重を表す。図3の破線は，全荷重を完成時の桠造物に截荷させた場 合の荷重係数と A 点の鉛直変位の関係を示したものである。すなわ ち,破線の関係は施工手順を考慮しない場合の変形性状を意味する。 同図より,施工時の荷重と変位の関係は, 各施工プロセスにおいて は線形であるにもかかわらず,施工経路全体から見れば非線形とな る。一方,施工手順を考應しない場合の両者の関係は線形となる。ま た、施工手順の考虑の有無によって最終形状が異なることもわかる。 すなわち，施工前の製作形状が同じであっても，施工経路によって 施工後の完成形状は異なる。従って, 施工後の完成形状を目標形状 に一致させるためには，施工経路を考慮して施工前の製作形状を決 定する必要がある。

\section{2 施工经路考虑した留作形状济定問題の解析}

図4に施工経路を考虑して，完成時に目標形状を満足させるよう に施工前の製作形状を求める解析手順を示す。解析方法を以下に説 明する。

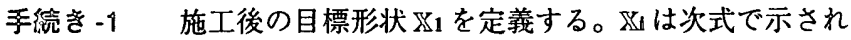
る座標べクトルである。

$$
\mathbb{X} i=\left[\mathrm{x}_{1}, \mathrm{y} 1, \mathrm{z} 1, \cdots, \mathrm{xn}_{1}, \mathrm{yn}_{\mathrm{n}} \mathrm{zn}\right]
$$

ここに, $(\mathrm{x}, \mathrm{yj}, \mathrm{zj})$ は節点 $\mathrm{j} の$ 座標, $\mathrm{n}$ は節点数を示す。

手统き手続き-3において, 施工後の完成形状を計算するため の初期形状 $\mathbb{X}_{2}$ を仮定する。

子続を-3 施工経路を考虑して, 完成形状欧を計算する。計算方 法は 2.1 節と同様とする。

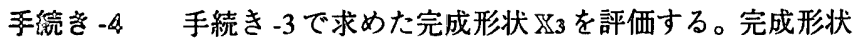
X3は, 次式で示すように目標形状区1との差異 $\Delta X$ K よって評価する。

$$
\Delta X=\frac{\sqrt{\left(X_{1}-X_{3}\right) \cdot\left(X_{1}-X_{3}\right)^{T}}}{3 n}<\varepsilon
$$

ここに，ยは完成形状の目標形状に対する許容差であ る。

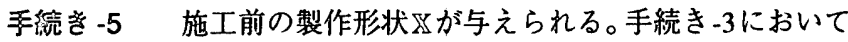
求めた完成形状 X3 3 が収束条件式(3)を満足する場合, 手続き-3で設定した初期形状 X2 2 を施工前の製作形状 区と決定する。

手躜き-6手続き-3において,施工後の完成形状を計算するため
の初期形状 X2 2 を更新する。手続き-3において求めた完成形状 $\mathbb{X}_{3}$ が 収束条件式(3)を渵足しない場合, 目標形状 $\mathbb{A}_{1}$ と完成形状边 3 との差 異を用いて次式のように初期形状远をを更新する。

$$
X_{2}=X_{2}+\left(X_{1}-X_{3}\right)
$$

製作形状を決定するに当り，上記の手続き-3〜 6の収束計算が必 要となる。これは, 初期形状によって剛性が異なるためである。例 えば，図1の構造物に製作キャンバーを設けた場合の剛性は，キャ

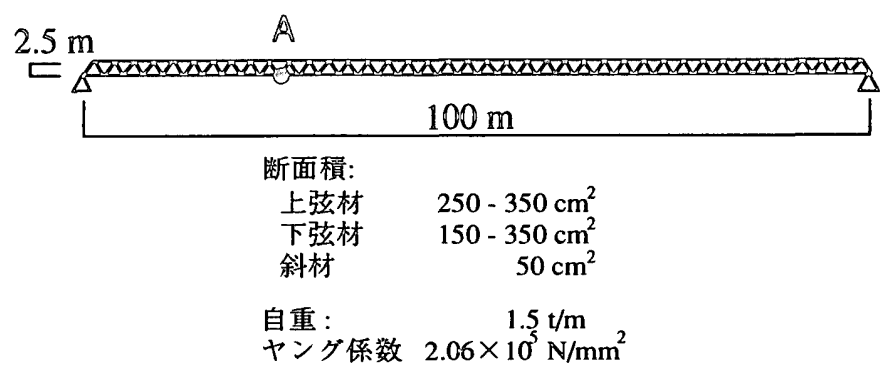

图 1 解析モデル

\section{プロセス-1}

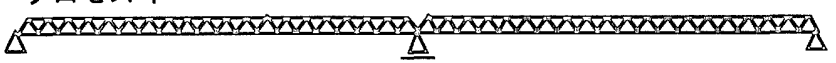
ブロックの架設

ブロセス-2

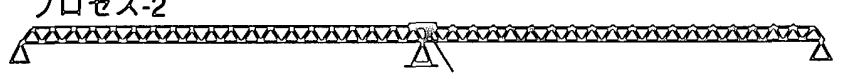
ブロックの接合

ブロセス-3

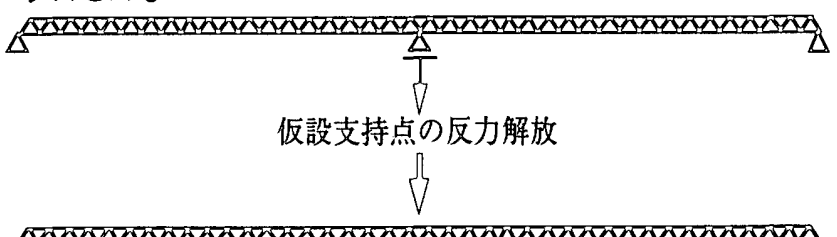
A 完成

圆 2 施工手順

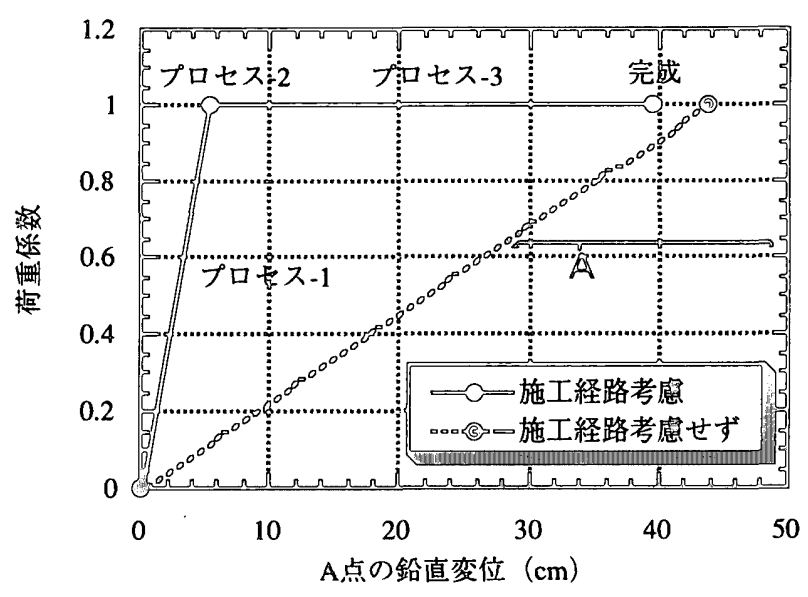

圆 3 施工時の变形性状 
手続き-1

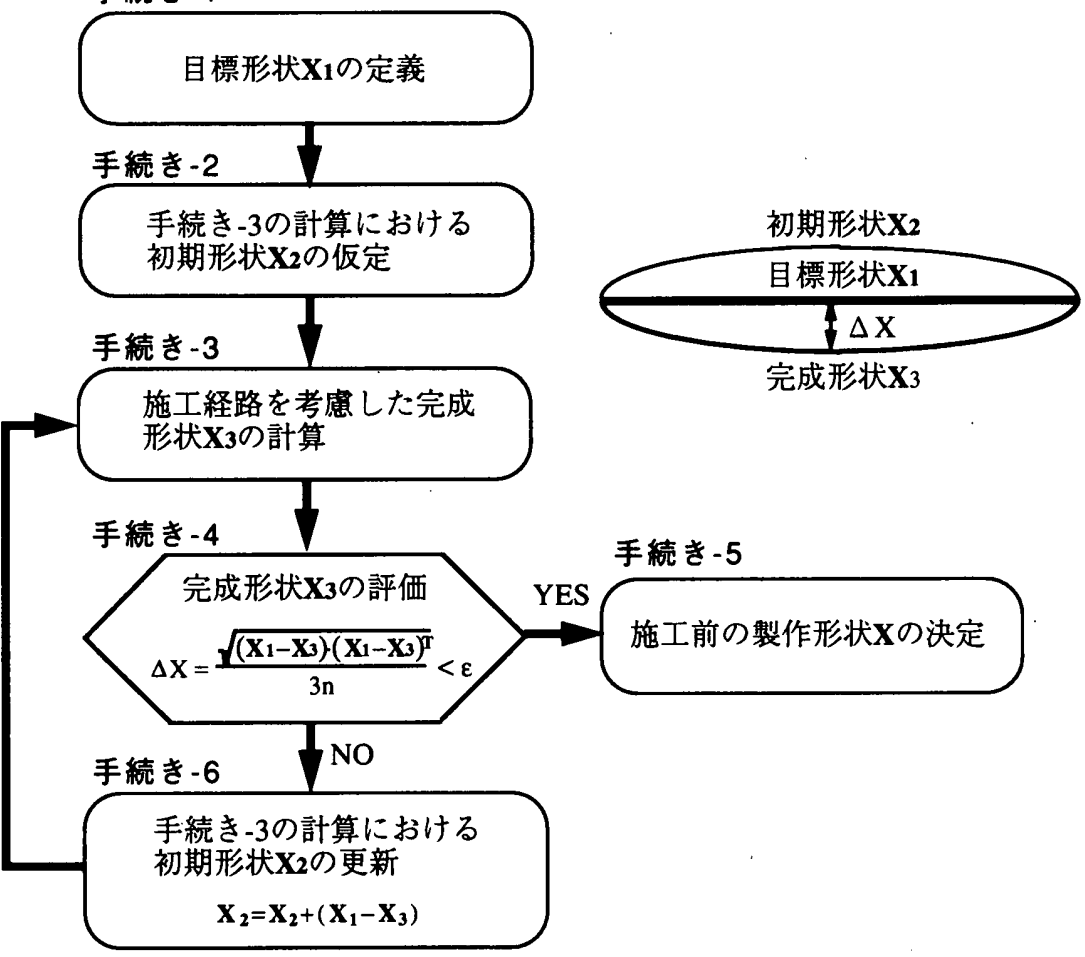

図4 施工経路を考慮した製作形状決定問題の解析手順

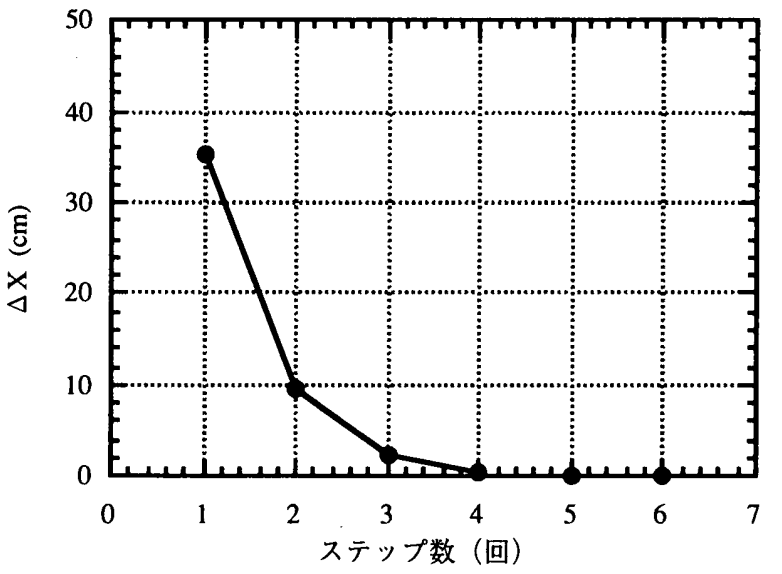

図 $5 \Delta \mathrm{X}$ の変化 $($ ケース -1$)$

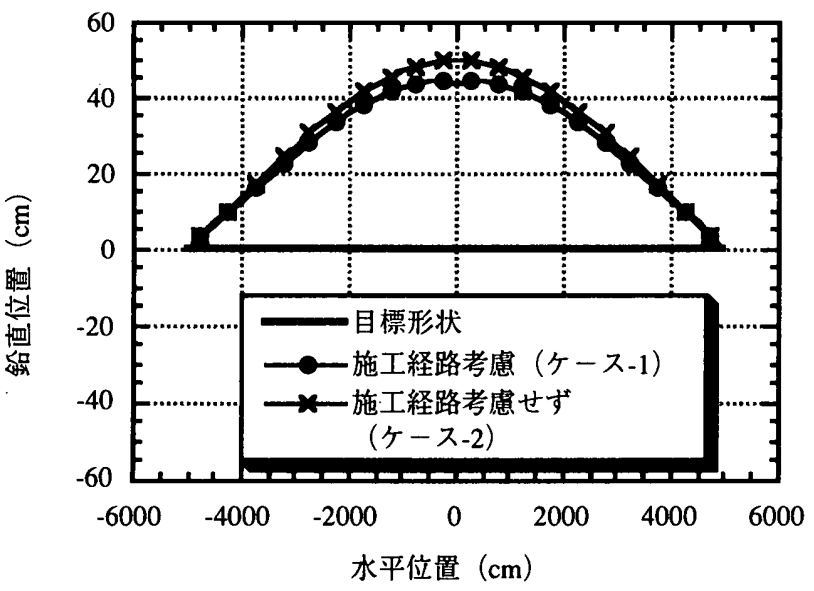

図 7 施工経路の考慮の有無による製作形状 $\mathbf{x}$ の相違

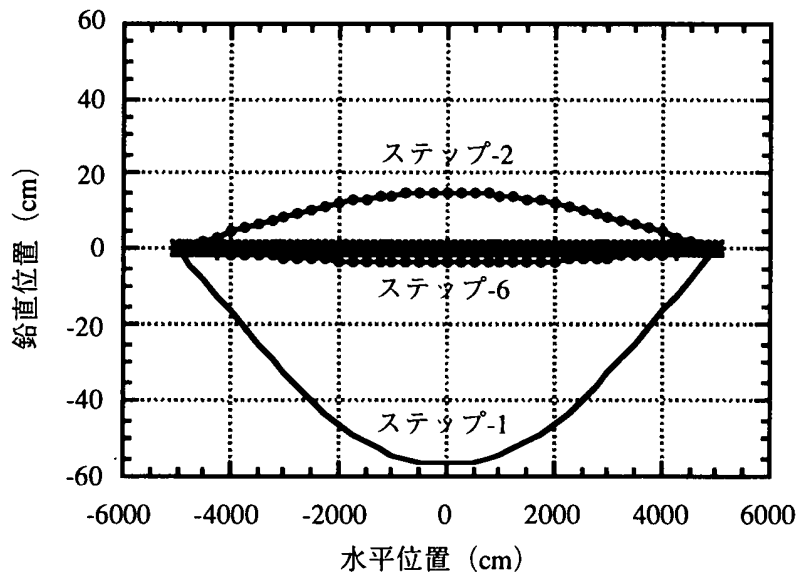

図 6 収束計算における完成形状 $\mathbf{X 3}$ の変化（ケース -1）

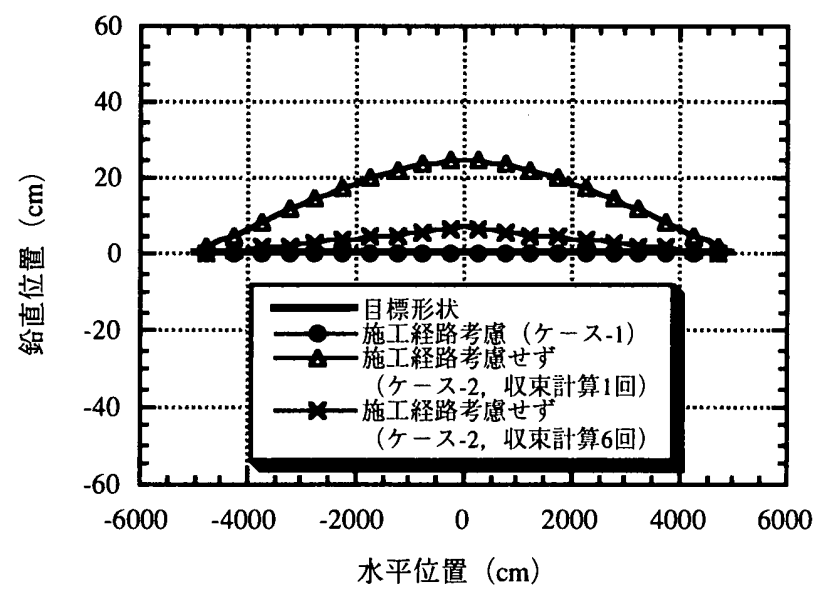

図8 施工経路の考虑の有無による完成形状 $\mathbf{X 3}$ の相違 
ンバーを設けないフラットな形状の剛性とは異なり,変形も異なる。

\section{3 解析例}

図 1 に示すトラス構造物を図 2 に示す手順で施工する場合の製作 形状を，施工経路を考虑して求める。施工時の荷重は自重（等分布 荷重)のみとする。解析は, 施工経路を考慮した場合 (ケースー1)お よび施工経路を考慮しない場合（ケース－2）の2ケースについて行 う。すなわち，ケース-1では，全荷重をプロセス-1で截荷し，第 $\mathrm{i}$ プロセスの変形は(1)式によって計算する。ケース-2では, プロセス1 3の施工段階を無視し, 完成時の構造物に全荷重を载荷した場合 の変形を計算する。目標形状 81 は图 1 に示すようなフラットな形状 とする。収束計算（手続き $-3 \sim 6$ 間の計算）前の初期形状这 2 は目標 形状区1と同じとする。完成形状の目標形状に対する許容差 $\varepsilon$ は 0.1 $\mathrm{cm}$ とする。

図 5 に収束計算における完成形状と目標形状との差 $\Delta X$ の変化を 示す。图6に手続き-3における計算によって得られた完成形状好（下 弦材の節点位置) の変化を示す。图 $7 に 2$ ケースの施工経路に関し て求めた製作形状 (下弦材の節点位置)を示す。ケースー1において, (3)式を满足する製作形状は 6 回の収束計算で得られた。

図 8 の®印は，ケース-1, すなわち，施工経路を考慮して求めた 踣作形状を初期形状として，図2の手順で施工した場合の完成時の 形状 (下弦材の節点位置) を示したものである。施工経路を考虑し たケースー1の場合, 施工後の完成形状は目標形状とほほ一致してお り, 本解析の有効性がわかる。

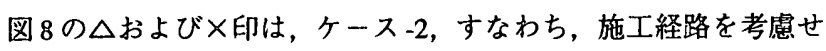
ず求めた製作形状を初期形状として，図2の手順で施工した場合の 完成時の形状を示したものである。 $\Delta$ 印は，手続き-3〜6の収束計 算を 1 回のみ行うことによって得られた製作形状を初期形状として おり，(3)式の条件は満足していない。 $\Delta$ 印の解析ケースは, 目標形状 に全荷重を戴荷した時の変形の逆变形（むくり）を，目標形状に対 して与えた形状を初期形状とした場合で, 製作キャンバーの一般的 な設計方法である。X印は，手続き $-3 \sim 6$ の収束計算を(3)式の条件 を満足するまで行うことによって得られた製作形状を初期形状とし た結果である (収束計算6回)。施工経路を考雇せず製作形状を評価 した場合，施工後の完成形状は目標形状とは異なることがわかる。

\section{3. 施工経路最適化問題の解析}

\section{1 部衫除去による逆施工经路解析}

一般的に, 構造部材の架設手順は組み立てる順序に従って計画さ れる。構造的視点に立つと,この従来型の架設計画は, 実續と経験 によって数種穎の架設手順を仮定し, 手順に沿った解析によって得 られた構造特性を，設定した目標と比較・評価することによって行 われる。その評価値が最も高い手順案が実施計画案となる。この計 画法は，仮定した手順を検証することによって行われることおよび 実績と経験をべースにしていることから、コンピューターなどによ る計画のシステム化を図ることが困難である。従って, 試行錯誤的 作業が多くなり，作業効率も悪い。この問題を解決する方法として， 架設手順を逆に追うことによって最適施工経路を探索する方法，い わゆる「逆施工経路解析》」が考えられる。この考えは,ケーブル構
造の最適な張力導入手順を探索する方法としていくつか実續がある 899)。これは, 完成時の張力導入状態から, ケーブル張力を逐次除去 していく方法である。

本諭文では，一般的なトラス構造物に関して，完成状態から部材 を除去することによって, 設定した目標に適合する施工経路を求め る解析について検討する。具体的に言えば, 部材を除去した後の構 造特性が設定した条件を渵足するように, 部材除去順序を求める。 組み上げる部材を選択・決定することに比べ，除去すべき部材の選 択・決定は, 構造特性から論理的に行えることから, 部材除去によ る逆施工経路解析はコンピューターなどによる計画のシステム化に 適すると考えられる。

本論文では, 施工経路最適化問題の評価関数として, 仮設支持部 材の数量を考える。仮設支持部材の数量合計が最小となる施工経路 を最適とする。ここでいう仮設支持部材は, 部材を除去する過程で, 次の条件 a)b)を満足しない場合に, 同条件を満足させるために節点 上に設ける仮設の支持点（節点変位を 0 にする点）を意哧する。

1) 安定である。

2) 部材軸力が許容軸力以下である。 条件 1)2)が本問題における制約条件となる。

また, 仮設支持部材の数量は, 仮設支持点の反力と数によって以 下のように評価する。

a) 仮設支持点の反力が小さいほど, 仮設支持部材の数量は少ない。

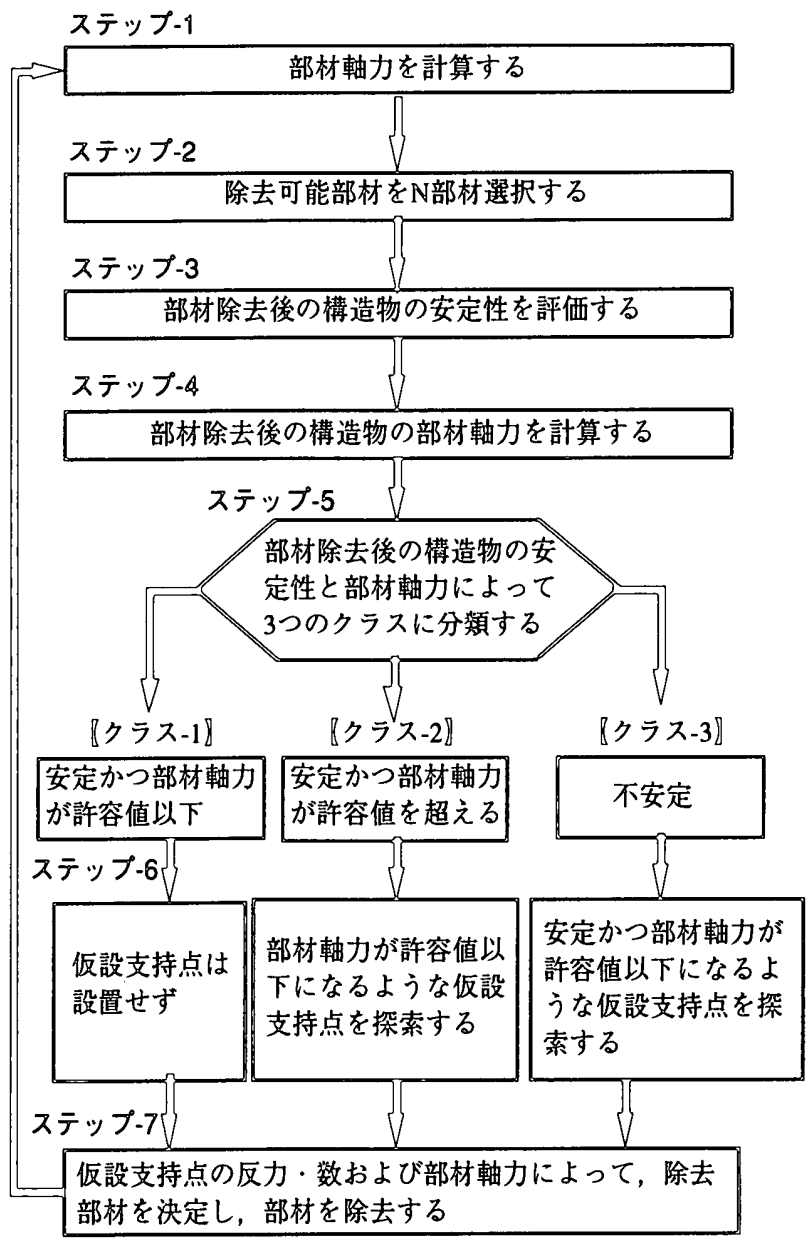

图 9 部材除去による逆施工経路解析手順 
b) 仮設支持点の反力が同じ場合は,仮設支持点数が少ないほど, 仮設支持部材の数量は少ない。

\section{2 解析方法}

図 9 に部材除去による逆施工経路解析の手順を示す。以下に解析 方法を説明する。なお, 荷重は各施工段階に存在する部材の自重の みを考慮する。

ステップ -1 部材 $\mathrm{i}$ の軸力 $\mathrm{n} 0 \mathrm{i}$ を計算する。

ステップ-2 全部材から, 軸力が小さい順に $\mathrm{N}$ 部材選択し, 除去可 能部材とする。ここでは, $\mathrm{N} /($ 部材除去前の部材数 $) \fallingdotseq$ 0.5 とする。除去可能部材を N 部材に限定するのは, ス テップ-3〜7の計算量を隇らすためである。除去部材 として，軸力が小さい部材を優先させるのは，除去す る部材の軸力が小さいほど, 部材除去後の構造物にお ける仮設支持点の反力が小さく, 部材除去前に対する 部材軸力の増大も小さいという仮定に基づく。

ステップ-3 部材除去後の構造物の安定性を評価する。安定性の評 価は，ステップ-2で選択した除去可能部材（N 部材） を各々,1本ずつ除去したNケの構造物に関してのみ行 う。 $\left|\mathbf{K}_{\mathrm{j}}\right|=\mathbf{0}$ の場合, 不安定とする。ここに, $\mathbf{K}_{\mathbf{j}}$ は第 $\mathrm{j}$ 番 目の施工段階における構造物の剛性マトリクスである。

ステップ -4 部材除去後の構造物の軸力 $\mathrm{nji}$ を計算する。軸力の計算 は，ステップ-2で選択した除去可能部材（N 部材） を各々,1本ずつ除去したNケの構造物に関してのみ行 う。

ステップ -5 部材除去後の構造物の安定性および軸力によって，3 つのクラスに分類する。

・クラス -1 安定かつ $|\mathbf{n j i}| \leq|\mathbf{n a l}|$

・クラス -2 安定かつ $\left|\mathbf{n}_{\mathrm{j} i}\right|>\left|\mathbf{n a l}_{\mathrm{a}}\right|$

・クラス -3 不安定

ここに, nal は許容軸力を示す。軸力 $\mathbf{n}_{\mathrm{ji}}$ は全部材に関し て評価する。本ステップの評価は,ステップー2で選択 した除去可能部材（N部材）を各々，1本ずつ除去した Nヶの構造物に関してのみ行う。

ステップ-6 ステップ-5で分類したクラスに従って，仮設支持点の 位置および反力を算定する。各クラスによって以下の ように算定する。

・クラス -1 仮設支持点は設けない。

・クラス -2 $|\mathbf{n j} \mathrm{j}| \leq|\mathbf{n a l}|$ を満足する仮設支持点を探索 し, 仮設支持点の反力 $\mathbf{R} \mathbf{j}$ を計算する。こ こに, $\mathrm{k}$ は仮設支持点番号を示す。

・クラスー3 剛体変位モードを拘束し ${ }^{10)}$, かつ $\left|\mathbf{n}_{\mathrm{j} j}\right| \leq \mid$ nal $\mid$ を満足する仮設支持点を探索し，仮設支 持点の反力 $\mathbf{R}_{\mathrm{jk}}$ を計算する。

ステップ -7 次の手順に従い, 除去部材を決定する。

a)ステップ-5において，除去可能部材は各々 1 3の クラスに対応する。ステップ-2で選択した除去可能部 材から, 最小のクラス番号を有する除去可能部材を選 択する。 b)ステップa)で選択した除去可能部材から，仮設支持 点の反力ノルム $\|\mathbf{R} \mathrm{j}\|=\sum^{\mathrm{n}}|\mathbf{R} \mathrm{j}| \mathrm{k} \mid$ が最小となる除去可能部

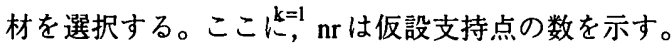
c)ステップb)で選択した除去可能部材から，仮設支持 点数が最小となる除去可能部材を選択する。

d)ステップc)で選択した除去可能部材から，軸力ノル

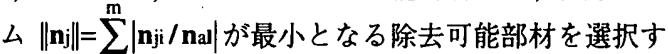
る。ここ港, $\mathrm{m}$ は部材除去後の構造物の部材数である。

\section{3 積層構造物の解析例}

解析モデルとして，図 10(a)に示す積層構造物（トラス要素で構成 した静定構造物）を採用する。施工時の荷重は自重のみとする。許 容軸力は完成構造物の自重時における軸力と同じとする。図9のス テップ -2 における選択部材数 $\mathrm{N}$ は, $\mathrm{N}=($ 部材除去前の部材数) $\times 0.5$ とする。表 1 に, 図 11 のステージ-1における図9のステップ-1〜7 の評価結果を示す。ステージ-1では, 軸力の小さい順に選択する $\mathrm{N}=12 \times 0.5=6$ 部材の除去可能部材に関して, 部材除去後の構造物は すべて, 不安定, クラス -3 , 反カノルム $\|\mathbf{R} j\|=0.0$ および仮設支持点 数=0である。従って, ステップ-7d)の評価より, 部材除去後の構造 物の軸力ノルム $\|\mathbf{n} \mathbf{j}\|$ が最小となる部材番号9の部材を除去部材とし て選択する。図 11 に本解析で得られた部材除去の順序を示す。実際 の架設は図11で示される順序の逆に行われる。得られた結果は積層 構造物の代表的工法の積み上げ工法である。この結果は，本解析に よって実際の架設手順を探索できることを示唆している。

\section{4 片持梁の解析例}

解析モデルとして，図 10(b)に示す片持梁（トラス要素で構成した

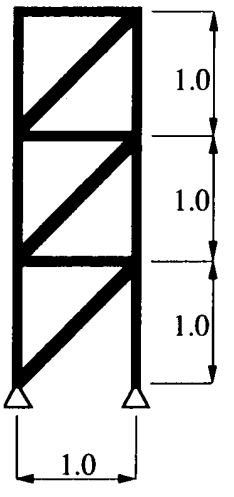

(a)積層構造物モデル

$$
\begin{array}{ll}
\text { 断面積 } & \mathrm{A}=1.0 \mathrm{~cm}^{2} \\
\text { ヤング係数 } & \mathrm{E}=98.1 \mathrm{~N} / \mathrm{mm}^{2} \\
\text { 単位体積重量 } \quad \rho=1.0 \mathrm{t} / \mathrm{cm}^{3} . \\
\text { 長さの単位は } \mathrm{cm}
\end{array}
$$

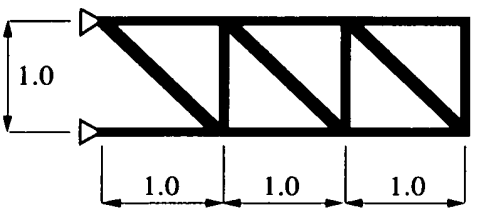

(b)片持梁モデル

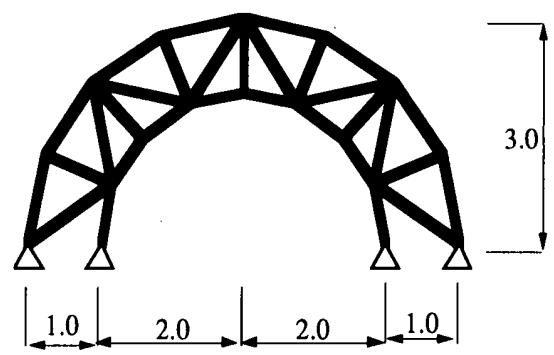

(c)アーチモデル

図 10 解析モデル 


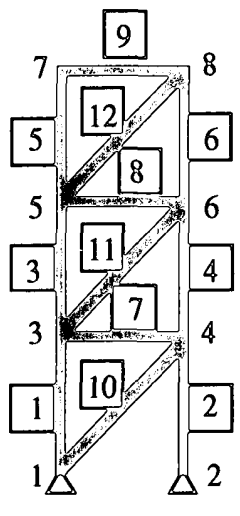

ステージ-1

(3)

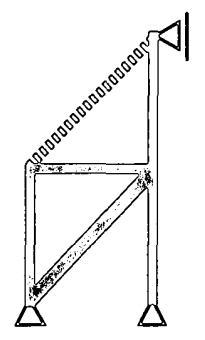

ステージ-8

(1)

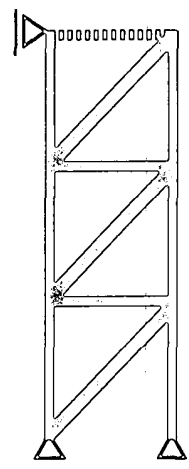

(1)

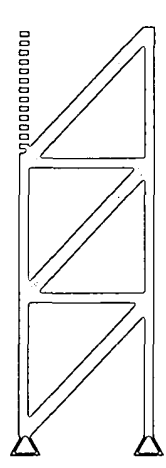

テージ-3

(3)

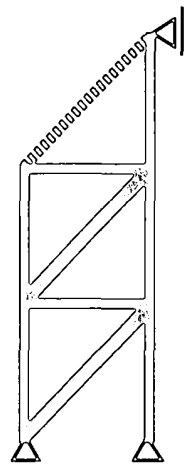

ステージ-4

(1)

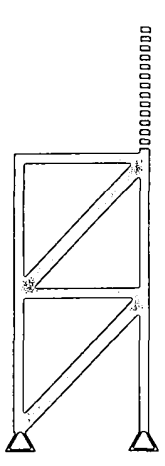

ステージ-5

(3)

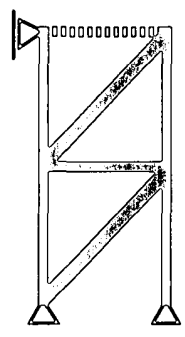

ステージ-6

(1)

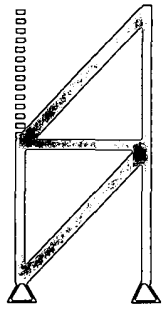

テージ-7

(3)

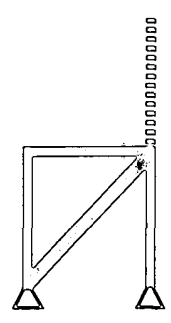

ステージ-9

(3)

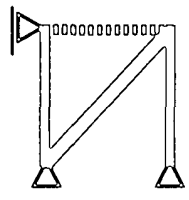

ステージ-10

(1)

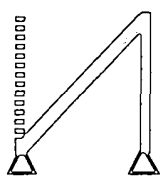

ステージ-11

(3)

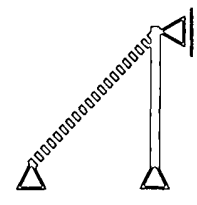

ステージ-12

(1)
圆11得られた施工経路 （䅡層構造物モデル）
注 1)（）内数字はステップ-5で分頶したクラス番号（最小値）を示す。 注 2) 破線は当該ステージの前ステージにおいて除去する部材を示す。 注 3) $\triangleq$ は仮設支持点を示す。

注 4)ステージ-1の図中における数字は節点番号を，口内数字は部材番号を示す。

蒜1図 11 に示すステージ-1の評価結果（䅡層構造物モデル）

\begin{tabular}{|c|c|c|c|c|c|c|c|c|c|c|}
\hline $\begin{array}{l}\text { ステッ } \\
\text { プ番号 }\end{array}$ & 1 & 2 & 3 & 4 & 5 & \multicolumn{4}{|c|}{6} & 7 \\
\hline $\begin{array}{l}\text { 部材 } \\
\text { 番号 }\end{array}$ & $\begin{array}{c}\text { 軸力 } \\
(\mathfrak{t})\end{array}$ & 函先順位 & $\begin{array}{l}\text { 安定性 } \\
\text { の評価 }\end{array}$ & $\begin{array}{c}\text { 軸力の } \\
\text { 評価 }\end{array}$ & クラス & $\begin{array}{l}\text { 仮設支持 } \\
\text { 点およ訪 } \\
\text { その方向 }\end{array}$ & $\begin{array}{c}\left\|\mathbb{R}_{\mathbf{j}}\right\| \\
(\mathbb{t})\end{array}$ & $\begin{array}{c}\text { 仮設 } \\
\text { 支持数 }\end{array}$ & $\left\|\mathbb{m}_{j}\right\|$ & $\begin{array}{l}\text { 除去 } \\
\text { 部材 }\end{array}$ \\
\hline 9 & 0.00 & 1 & 不安定 & - & 3 & $7 x$ & 0.00 & 1 & 4.75 & $\bigcirc$ \\
\hline 12 & 0.00 & 1 & 不安定 & - & 3 & $7 x$ & 0.00 & 1 & 4.94 & \\
\hline 7 & 0.00 & 1 & 不安定 & - & 3 & $3 x$ & 0.00 & 1 & 5.83 & \\
\hline 8 & 0.00 & 1 & 不安定 & - & 3 & $5 x$ & 0.00 & $\mathbb{1}$ & 5.54 & \\
\hline 11 & 0.00 & 1 & 不安定 & - & 3 & $5 x$ & 0.00 & $\mathbb{1}$ & 5.57 & \\
\hline 10 & 0.00 & 1 & 不安定 & - & 3 & $3 x$ & 0.00 & 1 & 5.88 & \\
\hline 5 & -1.00 & 7 & \multicolumn{8}{|c|}{ 評価せず } \\
\hline 6 & $-1.7 \mathbb{1}$ & 8 & \multicolumn{8}{|c|}{ 評価せず } \\
\hline 3 & -3.21 & 9 & \multicolumn{8}{|c|}{ 評価せず } \\
\hline 4 & -3.91 & 10 & \multicolumn{8}{|c|}{ 評価せず } \\
\hline 1 & -5.41 & 11 & \multicolumn{8}{|c|}{ 評価せず } \\
\hline 2 & -6.12 & 12 & \multicolumn{8}{|c|}{ 評価せず } \\
\hline
\end{tabular}




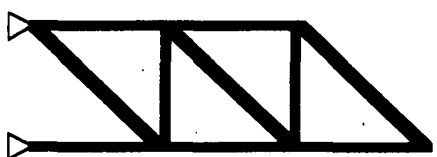

ステージ-1

(3)

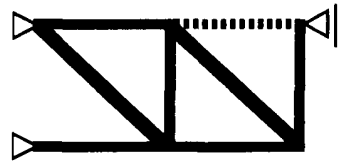

ステージ-4

(1)

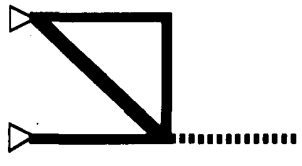

ステージ-7

(3)

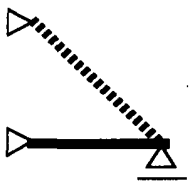

ステージ-10

(1)

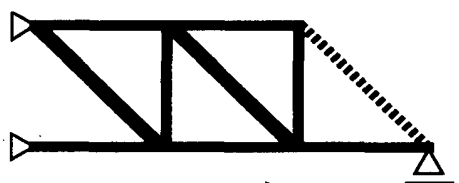

ステージ-2

(1)

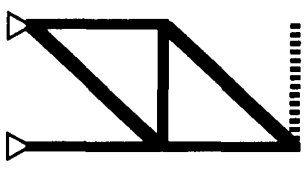

スデージ-5

(3)

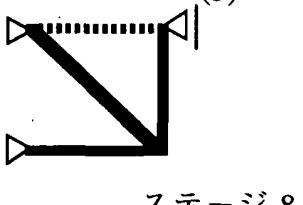

(1)

$\triangleright$

\section{Diı..........!}

ステージ-12

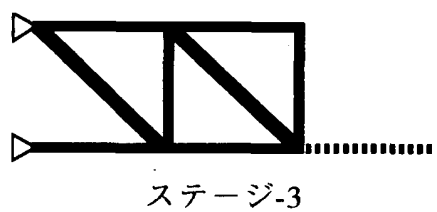

(3)

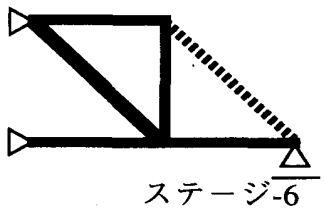

(1)

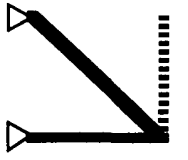

ステージ-9

(3)

図 12 得られた施工経路（片持梁モデル）

静定構造物）を用いる。施工時の荷重は自重のみとする。許容軸力 は完成構造物の自重時における軸力と同じとする。図12に本解析で 得られた部材除去の順序を示す。実際の架設は図 12 で示される順序 の逆に行われる。得られた結果は, 支持端から梁先端に向かって. 仮 設支持 $\rightarrow$ 仮設支持反力の解放を順次繰り返す工法である。

\section{5 アーチの解析例}

解析モデルとして，図10(c)に亦すアーチ（トラス要素で構成した 不静定構造物）を用いる。施工時の荷重は自重のみとする。許容軸 力は完成構造物の自重時における軸力の3倍とする。図 13 に本解析 で得られた部材除去の順序を示す。実際の架設は図13で示される順 序の逆に行われる。得られた工法は, 上弦アーチを両支持端から上 方へ順次架設し，上弦ア一千架設終了後，下弦材と斜材を両支持端 近傍から上方へ順次架設する工法である。同工法は，吊り橋の片持 式工法に近い工法である。

\section{4. まとめ}

本論文は，実績と経験によって試行錯誤的に行っている施工計画 に,コンピューター支援による理論解析的手法を導入することを試 みたものである。施工計画に関して, 製作形状決定問題および施工 経路最適化問題の解析手順の提案および解析方法を述べた。提案し た方法を実際の構造物に適用し数值解析を行った結果, 以下のこと が明らかになった。

(1)施工前の構造部材の製作形状は, 図4に示す解析手順によって求 めることが可能である。

(2)卜ラス構造物に関して, 施工時の仮設支持部材の数量を最小にす る構造部材の架設手順は, 図9に示す部材除去による逆施工経路解
析によって求めることが可能である。

\section{参考文献}

(1)宮武保義, 山崎雄介：“建築生産システムの革新をめざして一 CIC to TRY2004", 施工, pp.158 167，1992 年 1 月

(2)土木学会構造工学委員会: “構造システム最適化の現状と将来”, 土 木学会論文集, No.450/l-20, pp.1 12, 1992 年 7 月

(3)岩松幸雄, 早川裕史, 原田隆郎: “橋梁の比較設計支援エキスパー トシステムに関する研究”，土木学会論文集，No.453/VI-17, pp.51〜 57,1992 年 9 月

(4)植木隆司：“空間骨組構造 形態·性能·生産 施工中の形態”, 日 本建築学会シェル・空間構造運営委員会, pp.115～128，1995年 12 月 (5)兼光知巳, 半谷裕彦:”建築構造物施工のための部材配置問題一施 工経路を考虑した製作形状決定”，日本建築学会大会学術講演梗概集 (近畿)，pp.453 454，1996 年 9 月

(6)池田宏之, 谷口伸一郎, 皿海康行, 吉田篤也：“タケノコ工法によ る展望塔のリフトアップ”，施工，pp.24〜 39，1994 年 10 月

(7)兼光知巳, 半谷裕彦:" 建築構造物施工のための部材配置問題一部 材除去による逆施工経路解析”，日本建築学会大会学術講演梗概集 (北海道)，pp.461 462，1995 年 8 月

(8)斉藤公男, 黒木二三夫 : "ケーブルネット構造の構成解析”, 日本 建築学会大会学術講演梗概集 (関東), pp.717 718, 昭和 50 年 10 月 (9)荒瀬誠, 斉藤公男, 岡田章, 安部裕：”ケーブルによるタワーの構 造特性及び施工計画”, 日本建築学会大会学術講演梗概集 (北海道), pp.781 782, 1995 年 8 月

(10)半谷裕彦, 川口健一: " 形態解析”, 培風館, pp.67 84, 1991 年 4 月 


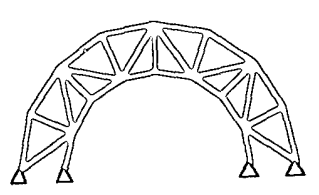

ステージ-1(1)

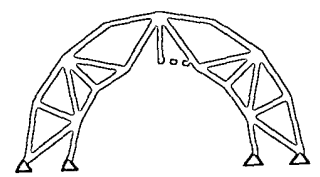

ステージ-5(3)

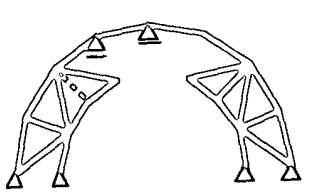

ステージ-9(3)

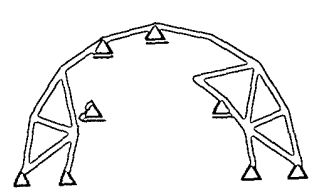

ステージ-13(1)

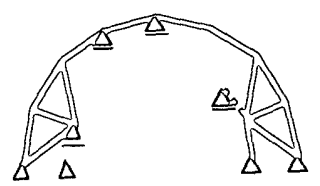

ステージ-17(1)

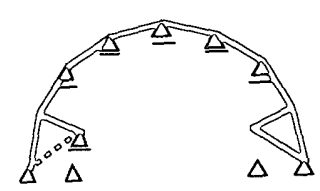

ステージ-21(3)

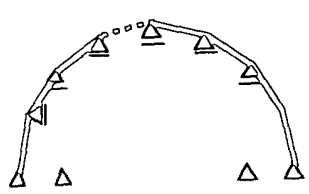

ステージ-25(3)

$\Delta \Delta$

ステージ-29(1)

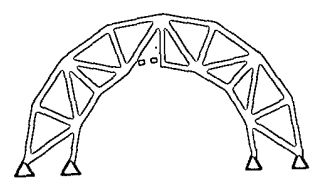

ステージ-2(1)

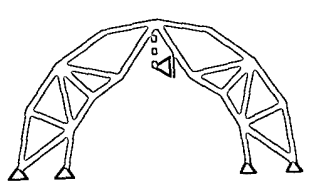

ステージ-6(1)

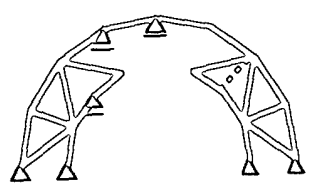

ステージ-10(3)

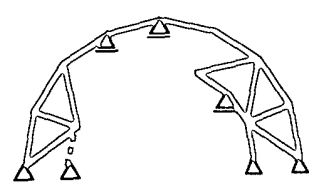

スデージ-14(3)

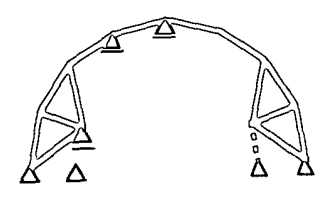

ステージ-18(1)

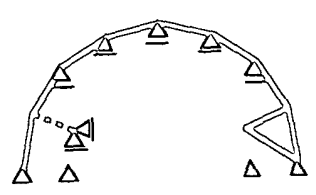

ステージ-22(3)

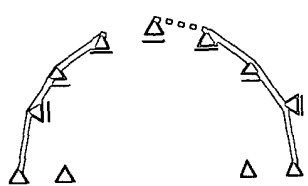

ステージ-26(1)

$\Delta \Delta \underbrace{\Delta}_{\Delta}$

ステージ-30(1)

$\Delta \mathbb{R}$

$\triangle 1$
0
0
0
$\Delta \Delta$

$\Delta \Delta$

ステージ-31(1)

䀡 13 得られた施工経路（アーチモデル）

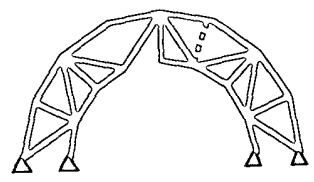

ステージ-4(1)

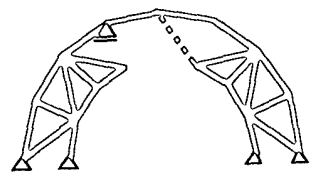

ステージ-8(3)

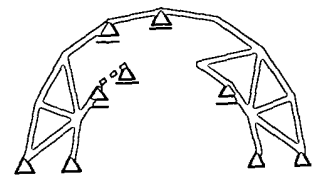

ステージ-12(1)

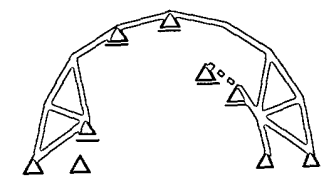

ステージ-16(1)

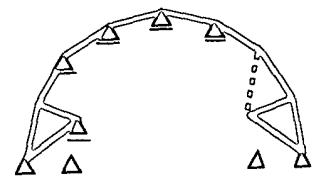

ステージ-20(3)

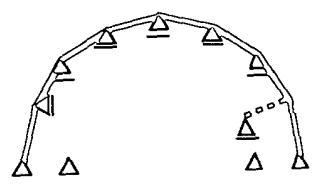

ステージ-24(1)

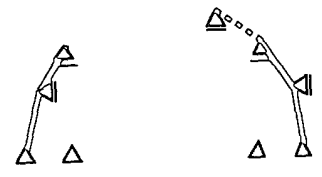

ステージ-28(1)

$\Delta \Delta$

$\Delta \quad \begin{array}{r}\Delta \\ 0 \\ 0 \\ 0 \\ 0\end{array}$

ステージ-32 